Ing. Mgr Martina Valachová,

Faculty of Law, Masaryk University,

Czech Republic

\title{
COUNTRY BY COUNTRY REPORTING
}

\section{Introduction}

$\mathrm{T}$ he necessity to secure a higher level of transparency in the area of international taxation places significant demands on Tax Authorities in individual countries as well as on multinational enterprises. With respect to the global financial crisis, the media and non-profit organisations started to point out the tax practices of big multinational companies, shifting the profits into countries with a lower tax burden. The reaction to such phenomenon was the Action Plan BEPS, put together by the OECD in cooperation with G20 countries. The Action Plan highlighted the value of transparency as one of the three fundamental pillars of the whole BEPS initiative, resulting in strengthening cross-border relations of Tax Authorities by implementing new legislation on transfer pricing documentation as well as by introducing country by country reporting instruments. These tools are established in point 13 of the Action Plan.

The objective of this paper is to explain and describe the instrument of Country by Country Reporting as well as to recall the potential practical impacts related to its implementation.

\section{Point 13 of BEPS Action Plan}

The release of the Action Plan in July 2013 clearly affirmed the fact that transfer pricing holds a substantial position. This matter is included in point 13 of the Action Plan
- Transfer Pricing Documentation, which together with the OECD Recommendations imposes significantly more serious requirements on multinational enterprises than ever before and provides Tax Authorities with a sufficient amount of information that enables them to assess the potential risk of base erosion and profit shifting.

This point was primarily formulated in order to secure the higher level of transparency which occurs as one of the fundamental pillars of the BEPS initiative. The focus on transparency inspired the OECD to create the framework for transfer pricing documentation which reflects the global business structures formed by multinational enterprises. In October 2015, the final set of OECD recommendations to BEPS Action Plan was released and contained the instructions for the transfer pricing documentation as well as the country by country reporting. The significance of this change can be seen in the fact that the overall Chapter V of the OECD Transfer Pricing Guideline was replaced by a version reflecting the new requirements for multinationals. ${ }^{1}$

The main characteristic feature of the OECD Transfer Pricing Guideline update is the introduction of the three step approach towards transfer pricing documentation. The reason for such an attitude was predominantly the necessity to provide the tax authorities of the individual countries with an effective tool securing a sufficient amount of relevant information. In the view of the OECD, this will help the tax authorities to identify the BEPS risks 
better. The three step approach presumes the following documents:

- master file;

- local file and

- country by country report. $^{2}$

The master file contains the detailed information about the overall operations of the multinational group as well as the transfer pricing policy. Such information should enable the tax authorities to create a sufficiently comprehensive idea about the relations between individual entities within the group and help to interpret the information provided in the local file as well as in the country by country report. The master file is a key document of the transfer pricing documentation in respect that it focuses on the transfer prices setting in the group as well as on the allocation of revenues and economic activities.

The local file includes detailed information about relevant operational transactions between the affiliated parties specifying the amounts and the analysis of the transfer prices setting in these transactions. The master file together with the local file are submitted to the tax authority in the country where the company is registered with no reflection to the parent company residence.

\section{Country by country reporting}

The third feature of the transfer pricing documentation is the country by country report. The main objective of its introduction is to provide the tax authorities with sufficient and relevant information about the nature of the activities as well as the information about global allocation of the generated revenues and the tax amounts paid in the individual countries. ${ }^{3}$ The obligation to create and submit such a report applies to multinationals whose consolidated revenues exceed the limit of EUR 750 million. The up-to-date OECD Transfer Pricing Guideline determines the list of indicators that companies must provide in every jurisdiction where the group operates. The list contains the following indicators:
- revenues (split between the related and non-related entities);

- profit or loss before income tax;

- income tax paid;

- income tax accrued;

- stated capital;

- accumulated earnings;

- number of employees and

- tangible assets (other than cash and cash equivalents). ${ }^{4}$

The key issue for the OECD was to determine appropriate rules for the manipulation with the information provided in the report including the resolution in which country the country by country report will be submitted. Another set of issues was to formulate the principles of sharing the data with the other tax authorities.

Unlike the master file and the local file, which are submitted to the specific tax authority according to entity place of residence, the country by country report will be submitted annually by the parent company for the overall group in the country of residency of the parent company. Such a report will then be provided to the tax authorities in whose countries the multinational company runs some business activities and the process will be held in accordance with the principles of the automatic exchange of information. ${ }^{5}$

In order to secure even more efficient and consistent implementation of the automatic exchange of the country by country reports in between the individual jurisdictions, the Multilateral Competent Authority Agreement on the Exchange of Country by Country Reports - the so-called CbC MCAA was developed. Such agreement stems from article 6 of the Multilateral Convention on Mutual Administrative Assistance in Tax Matters as well as from the Common Reporting Standard (CRS). The CbC MCAA enables the tax authorities to automatically exchange country by country reports under a well-established legal framework and in line with clear rules on confidentiality. The CbC MCAA further stipulates that the information received by the tax authority in compliance with the 
automatic exchange of country by country reports will only be used for conducting high level transfer pricing risk assessments, for evaluating the other BEPS risks and where appropriate for economic and statistical purposes. By no means will the information from country by country reports be used as a substitute for detailed transfer pricing analysis. ${ }^{6}$

\section{The implementation and the further development of the country by country reporting}

With regard to the fact that the final set of OECD recommendations to the BEPS Action Plan was approved by the G20 countries in November 2015, the member countries can focus on the local implementation of country by country legislative rules. It has been assumed so far that this instrument would be put into practice this year and that the first country by country report would be submitted in December 2017. The first practical use of such information would be in June 2018. At the same time the OECD is working on creating a platform for the electronic sharing of country by country reports. ${ }^{7}$

The figure below demonstrates the development and individual implementation stages of the country by country reporting.

Figure 1. Country by country reporting

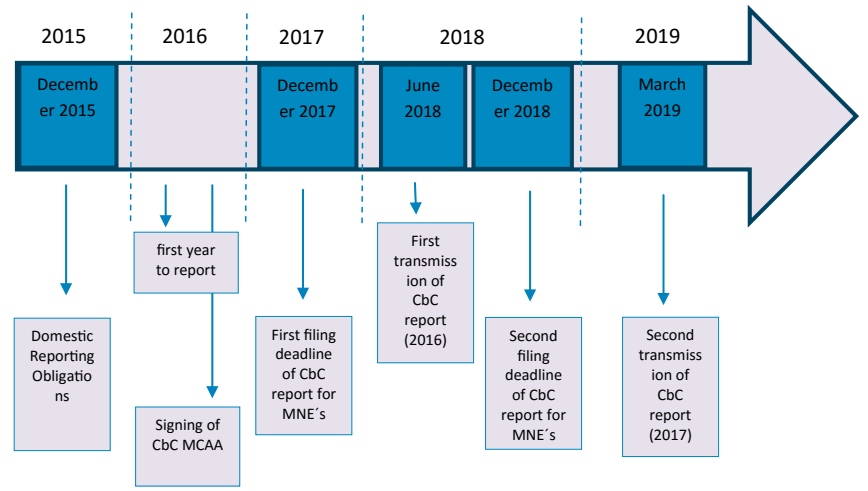

Zdroj: A. Hickman, S. Abdelghani, P. Honduis, Action 13: Transfer pricing documentation and country by country reporting. Cit. [8.1.2016]. Available at: http://www.internationaltaxreview.com/Article/3514685/
Action-13-Transfer-pricing-documentation-and-country-by-country-reporting.html.

As can be seen in the figure above, the CbC MCAA was signed in January 2016, which enabled the individual countries to start development of the international legal framework for sharing the country by country report. Numerous countries have already started introducing and approving the new country by country legislation. Significant measures were taken in Australia, Ireland, the Netherlands and the United Kingdom. ${ }^{8}$

\section{Potential practical impacts related to the country by country reporting}

However, point 13 of the BEPS Action Plan, specifically the country by country reporting tool, generates serious potential risks as well as an administrative burden for the multinational enterprises. These companies argue that the administrative costs of country by country reporting are very high. Nevertheless, more concerning is the fact that the tax authorities will have access to more information than ever before and they will interpret the transactions as a way of tax evasion. Another potential issue stems from the concerns that the information provided will be abused. The country by country data will be available to several tax authorities simultaneously, which increases the risk of potential information leak. ${ }^{9}$

However, the OECD fighting those arguments with the introduction of a special platform for electronic sharing of country by country reports as well as by implementing the sanction mechanism. When the country fails to secure the confidentiality of the data provided, it can be excluded from data sharing by the other countries. ${ }^{10}$

\section{Conclusions}

Point 13 of the Action Plan introduced the so-called three step approach to the transfer pricing documentation. The multinational companies in master file and local file will provide the required information on transfer prices 
setting, which enables the tax authorities to identify the potential risks of base erosion and profit shifting to the jurisdiction where it was not generated.

The multinational enterprises whose revenues exceed EUR 750 million have beside the master and local file the obligation to submit the country by country report, which contains the data that enable the tax authorities to gain a comprehensive idea about the business structures and the operational transactions between the entities. Such a report will be submitted by the parent company in the country of its residence for the overall multinational group. The tax authority of that specific country, holding the country by country report, will further share the report with the other tax authorities where the multinational company operates. The first country by country report will be submitted in December 2017 and will include the data for 2016. Therefore, in June 2018 the tax authorities should have access to the first set of data from country by country reports.

\section{$\underline{\text { Abstract }}$}

The three pillar approach to transfer pricing documentation makes multinational enterprises obliged to provide in master file, local file and country by country report the consistent transfer pricing positions that enable tax authorities to assess whether companies have engaged in transfer pricing practices that have the effect of artificially shifting substantial amounts of income into a tax-advantaged environment. The main goal of this contribution is to clarify the tool of country by country reporting and mention the potential issues of its implementation process.

\section{BIBLIOGRAPHY}

1. Hickman A., Abdelghani S., Honduis P., Action 13: Transfer pricing documentation and country by country reporting. Cit. [8.1.2016]. Available: http://www.internationaltaxreview.com.
2. McFarlane T., Transfer pricing documentation and country by country reporting, "Tax Journal", October 2015, Issue1283. Cit. [8.1.2016]. Available at: http://www.taxjournal. com.

3. OECD, Action 13: Guidance on the Implementation of Transfer Pricing Documentation and Country by Country Reporting. Cit. [8.1.2016]. Available at: http://www.oecd. org.

4. OECD, Action 13: Re-examine transfer pricing documentation. Cit. [8.1.2016]. Available at: http://www.oecd.org.

5. OECD, Transfer Pricing Documentation and Country by Country Reporting, Action 13 - 2015 Final Report. Cit. [8.1.2016]. Available at: http://www.keepeek.com.

OECD, Transfer Pricing Documentation and Country by Country Reporting, Action 13 - 2015 Final Report. Cit. [8.1.2016]. Available at: http://www.keepeek.com/ Digital-Asset-Management/oecd/taxation/transfer-pricing-documentation-and-country-by-country-reporting-action-13-2015-final-report_9789264241480-en\#page1.

A. Hickman, S. Abdelghani, P. Honduis, Action 13: Transfer pricing documentation and country by country reporting. Cit. [8.1.2016]. Available at: http://www. internationaltaxreview.com/Article/3514685/Action-13-Transfer-pricing-documentation-and-country-by-country-reporting.html.

OECD, Transfer Pricing Documentation and Country by Country Reporting, Action 13 - 2015 Final Report. Cit. [8.1.2016]. Available at: http://www.keepeek.com/ Digital-Asset-Management/oecd/taxation/transfer-pricing-documentation-and-country-by-country-reporting-action-13-2015-final-report_9789264241480-en\#page1.

T. McFarlane, Transfer pricing documentation and country by country reporting, "Tax Journal", October 2015, Issue 1283. Cit. [8.1.2016]. Available at: http://www. taxjournal.com.

A. Hickman, S. Abdelghani, P. Honduis, Action 13: Transfer pricing documentation and country by country reporting. Cit. [8.1.2016]. Available at: http://www. internationaltaxreview.com/Article/3514685/Action-13-Transfer-pricing-documentation-and-country-by-country-reporting.html.

OECD, Action 13: Guidance on the Implementation of Transfer Pricing Documentation and Country by Country Reporting. Cit. [8.1.2016]. Available at: http://www.oecd. org/ctp/beps-action-13-guidance-implementation-tp-documentation-cbc-reporting.pdf.

A. Hickman, S. Abdelghani, P. Honduis, Action 13: Transfer pricing documentation and country by country reporting. Cit. [8.1.2016]. Available at: http://www. internationaltaxreview.com/Article/3514685/Action-13-Transfer-pricing-documentation-and-country-by-country-reporting.html.

${ }^{8}$ A. Hickman, S. Abdelghani, P. Honduis, Action 13: Transfer pricing documentation and country by country reporting. Cit. [8.1.2016]. Available at: http://www. internationaltaxreview.com/Article/3514685/Action-13-Transfer-pricing-documentation-and-country-by-country-reporting.html.

McFarlane, T. Transfer pricing documentation and country by country reporting. Tax Journal, October 2015, Issue1283. Cit. [8.1.2016]. Available at: http://www.taxjournal.com.

${ }^{10}$ OECD, Action 13: Re-examine transfer pricing documentation. Cit. [8.1.2016]. Available at: http://www.oecd.org/ctp/beps-frequentlyaskedquestions.htm\#Action13. 